УДК $316.3 / .4$

\title{
International Students in Siberian Universities: Informal Practices of Status Commodification
}

\author{
Yulia V. Elokhina* \\ Irkutsk State University \\ 1 Karl Marx Str., Irkutsk, 664003, Russia
}

Received 14.08.2018, received in revised form 23.10.2018, accepted 06.11.2018

The article presents a variety of international students' status commodification forms. The relations of Russian universities and international students are analysed in the focus of international students' subjectivity recognition. Basing on the intermediate results of the study which considers a set of semi-structured interviews with international students, the author shows that studies at the university are often a means of implementing a wide range of migration and other strategies.

Keywords: international students, commodification, informal practices.

Research area: sociology.

Citation: Elokhina, Yu.V. (2018). International students in Siberian universities: informal practices of status commodification. J. Sib. Fed. Univ. Humanit. soc. sci., 11(11), 1794-1804. DOI: $10.17516 / 1997-1370-0340$.

In recent years, the number of international students has been growing in Russia as a whole and some of its regions. According to the Ministry of education and science of the Russian Federation, in the 2016/2017 academic year 244.000.00 international students came to Russian universities to study under bachelor and master degree programmes (Kak inostrantsu podgotovitsia..., 2018). It is noted that their number will grow year by year due to the launched projects, "Export of Russian Education" in particular (Interview: Olga Vasil'eva, 2018). Most international students choose capital or federal universities, yet their number in regional universities is also growing. Thus, in Irkutsk State University, the number of international students under basic degree programs and additional educational programmes, including the Russian language courses, has increased by a third over the past few years. In the 2017/2018 academic

(c) Siberian Federal University. All rights reserved

* Corresponding author E-mail address: julflower@yandex.ru

This work is licensed under a Creative Commons Attribution-NonCommercial 4.0 International License (CC BY-NC 4.0). 
year, they were 746 from 37 countries there were 746 international students from 37 countries (Otchety..., 2006-2018).

On the one hand, the increase in number of international students allows the universities, especially regional ones, to compensate the outflow of Russian students to the capital. On the other hand, it makes it possible to declare the internationalization strategy successful implementation. After the number of international students has become one of the performance indicators for the university effectiveness, attracting international students has been an important reporting indicator.

However, the foreigners, especially those who come for short-term additional educational programmes or basic courses degree programs, are often perceived as one large mass of students, who are practically not involved in the socio-cultural life of the university, or an object of educational activities. Serious issues of international students' adaptation have only recently become a matter of the researchers' and university managers' attention. It is socio-cultural adaptation which implies the specifics of the region or the citizenship of the main flow of students arriving at a particular Russian university that often becomes an object of research (Grebennikova, 2010; Huang, 2014; Liakh, 2015). The analysis of international students' extracurricular practices is less common (Zhu, 2016).

Yet, it is not only the way the international students interact with the university, its departments, staff and other students that is the matter of importance, but also the way they build relationships with the host community by making use of their student status among them. In other words, this means the way the international students use the university not only for education, but also/or for other tasks indirectly related to education. This view leads to the issue of foreign students' subjectivity regarding their relations with host universities. In this perspective, the status of the student can be considered as not only fixing the prescribed system of relations, but also a resource that can be commodified in different ways and for different purposes.

\section{An international student's status commodification}

The issues of commodification in higher education are more often viewed in terms of commodification of knowledge or educational services as such (Pan'kova, 2017). The similar focus is given to the international students' choice of Russian universities. Analysing the Chinese students' motivation at Khabarovsk universities, E.O. Leont'eva identifies "long-term pragmatic" motives associated with future work and career and "pragmatic ones focused on short-term efficiency such as convenience, 
comfort, accessibility" as the leading groups of motives (Leont'eva, 2016). However, the example of international students proves that not only knowledge and competence are transformed into a commodity. The very status of a student can be a resource for obtaining certain benefits and advantages, including those expressed in monetary terms.

This article dwells upon some aspects of internationalisation, which are not customary to discuss as each student is important for the index of the university efficiency. Yet, international students are not such a homogeneous mass as it may seem from the reports, the matter being not just their citizenship. An international student comes to a Russian university with certain motivation. For some of them it is the status of a student that can be the symbolic capital as it ensures a legal stay at the territory of the Russian Federation, whereas it is an opportunity to combine study and work for the others.

It is worth while analysing several examples in order to show the "bonuses" (tangible and intangible) the foreigners can get from the status of a regional university student. The article bases on the intermediate results of the research which considers a set of semi-structured interviews with international students, expert interviews with the tourism sector representatives, materials about the interaction of the International Relations Department of Irkutsk State University with the students from China and European countries, analysis of the international students' notes and comments in social networks (primarily in Facebook and WeChat).

The article, therefore, presents the identified diversity of the international students' status commodification forms, the practices that are aimed at obtaining material "bonuses" and those that are not related to obtaining benefits among them.

\section{To study and work, to work and study}

One of the commodification forms is related to the fact that the students enrolled in basic educational programmes, according to the migration legislation of the Russian Federation, are officially allowed to work (with a work permit available). Obtaining a work permit is easier for a person with a student visa than for a foreigner who has entered the territory of Russia for the purpose of work. This circumstance largely contributes to the fact that international students do not only study but also actively work.

Their right to work is provided not only by the Russian legislation. For example, in Japan, the foreigners who have entered the country on a student visa can apply to the 
Migration service for a work permit. Still, they are allowed to work no more than 28 hours per week.

It cannot be said that the practice of international students' status commodification has appeared recently. Thus, in Irkutsk State University there is a whole group of international students who have been studying for fifteen - nineteen years. Having arrived at the preliminary training department to learn the language, the students stayed at the university longer: first, they completed the bachelor's programme and the master's programme, and then they did the master's degree in a different field and were ready to apply for a new master's programme. In this regard, a respondent's answer "Just love to learn" to the question "Why are you going to enrol for a master's programme for the third time?" seems curious at least (a male of about 33 years old, the 2018 interview).

The students from China have been actively combining their education with work as guides for the several last years. This is due to the massive influx of Chinese tourists. According to the official data of the Federal Agency for Tourism, 43.5 thousand Chinese citizens came to the Irkutsk region in 2016 (it is 158\% more than it was the previous year) (V 2016 godu...). Local travel companies, the companies engaged in transport services provision, and translators associations are also involved in the reception of tourists. Yet, these are guides who build the interaction with both tourists and employees in the tourist and service infrastructure are one of the most important elements of the business scheme for the reception and accompanying the Chinese tourists. A number of expert interviews with the employees in the tourism industry have revealed that there are many Chinese citizens among the guides. These citizens stayed in Russia on a student visa.

The professional guides' involvement in accompanying the tourist groups, undoubtedly, leads to the travel companies' cost increase. The easiest solution to minimise such costs is to attract Chinese citizens who have lived in the country for quite a period of time and, thus, managed to get acquainted with the peculiarities of the service sector. These citizens speak Russian to the extent necessary for confident communication. This is mostly true for the Chinese students of local universities. Being in Russia on the terms of a student visa, they have an opportunity to work with the groups of tourists on an irregular basis without a long-term employment contract. Despite the simplified system of obtaining a work permit, Chinese students do not always apply to the appropriate structures.

The reverse side of migrant students' orientation towards illegal work is a low quality of services. Our respondents mention the "illegal" guides' complete ignorance 
of the history, cultural contexts, and even geography and toponyms of the city and the places they show: "incredible nonsense", "complete nonsense", "the stories that have nothing in common with reality", etc. The poor quality of such a "tourist product" is compensated by low prices on the tours. This largely explains why these tours are bought by the Chinese people who are not the wealthiest. For the vast majority of Chinese tourists Irkutsk is not the end point, but a transit one on their trip to Russia. To a certain extent, tours of Irkutsk are a by-product but not the main product, purchased by Chinese tourists.

The routes and the list of cultural and historical sites for the tourist groups, accompanied by "illegal guides", almost completely coincide with the routes offered by the Russian travel operators. According to our respondents, they have no conflict situations with the Russian guides. As for the difference in the level of information provided by Russian and "illegal" guides, its awareness is mentioned in the interviews as exceptional and memorable cases.

Thus, Chinese students, who are actively involved in the sphere of tourist services but have no work permits, are an example of an illegal migrant employee's classical situation: legal stay and illegal employment. The result is the low cost of migrant labour and the lack of documentary evidence of its connection with the employer. This leads to price dumping in the market of guide-interpreters. In addition, due to a considerable number of such students in the region the companies do not take the responsibility if illegal work activities have been revealed.

The migration control authorities are trying to prevent such practices. Official explanations are given in oral form at the meetings with the university representatives. However, it is not always possible to stop such extralegal activities as it is quite difficult to document the difference between a Chinese student's communication with the fellow countrymen during their walk around the city and the guide services. The fact that communication with the potential consumers of tourist services can be built through social networks (primarily WeChat) and, thus, makes it possible to call business communications informal communication is also a challenge. The possibility to conclude contracts, as well as to effect all monetary payments through Chinese payment systems linked to social networks drops all the key signs of labour activity out of the Russian governing authorities' sight. The external observer is left with a completely innocent picture of a foreign student showing his friends the city where he had a chance to study.

Chinese tourists come to the region not only in large groups. Richer people buy individual tours, where Chinese students can play the role of guides. The programme 
of such tours is adjusted according to the order of the customers, the tourists move around the city or within the region in the personal transport of the Chinese guide. The demand for excursions outside the regional centre, primarily on the shores of Lake Baikal, has resulted in the formation of the practice of acquiring a used car by international students. One of the participants of the "group" registers the car in the State Road Traffic Safety Inspection, and it becomes an instrument for earning money and is used according to a predetermined schedule. This allows the students not to depend on official travel agencies and to form a programme of the stay for visiting tourists according to their specific needs.

There is some indirect data that allows to assume that Chinese students of local universities actively work not only as tour guides, but are also involved in trade and small business. Though the example with the illegal work as tour guides is the most vivid one in connection with the increased flow of Chinese tourists and a new wave of alarmist trends, which ran through regional and federal mass media.

There may be a feeling that the commodification of the student status is actively used only by representatives of Asian countries. However, students from European countries also quickly realize that, along with studying at a university, they can be engaged in part-time work. This is most often associated with activities as teachers, i.e. "native speakers" (most often English) in numerous language schools and courses of the spoken foreign language. As a rule, a job offer for a foreign specialist is associated with a number of rules to be followed, especially when it comes to teaching in accordance with additional educational programmes. Therefore, foreign students who are already legally in Russia are actively invited to work in language centres and schools, which, on the one hand, solve the problem of quality language training, and on the other hand, increase improve their image. It is not necessarily an American or an Englishman who can work as native speakers of English, for example, although they are most welcome to be hired in the language centres. The Swiss, Polish, Belgian, Swede (the list can be continued) can also cope with the role of a "native speaker" of the English language if no Englishman is available.

"I am from Poland and I am a teacher in a language school. People often think I am an Englishman, though I just say that I am from Europe. For me it is not so much the way to earn money, but an opportunity to meet new people", says the respondent who came to study in a regional university for 6 months on an exchange programme and who easily got a job in one of language centres (male, 20 years old, interviewed in 2018). 
When working as a teacher in accordance with additional education programmes, the student status is commodified through extralegal employment practices. However, unlike the activities of illegal guides, such work does not cause negative reactions in the host community because conflict of interest with Russian citizens is minimised. No negative reaction, as a rule, is observed in relation to the Chinese teacher, who works as a native speaker. The absence of conflict leads to the fact that these practices are completely out of sight.

\section{"Not by bread alone..."}

Commodification of the status by international students is connected not only with the desire to work in Russia. There is a number of other practices that are not directly related to obtaining material goods.

This is often related to personal relations. A foreigner comes to Irkutsk on a tourist or any other type of visa, meets his/her second half, but it turns out that the stay in the country on a tourist visa is not as long as the couple wants it to be. This problem can be solved by application to the nearest university and obtaining a student visa for a longer period of time. If a foreigner does not speak Russian, then they have to take Russian language courses or apply to the preliminary training departments available almost in all universities. Usually it is a Russian resident, who collects all necessary documents and fills in an application to a university. They contact the international department or the admission commission in order to solve all formal issues on behalf of their boyfriend/girlfriend. Often, a Russian boyfriend/girlfriend accompanies a foreign citizen in all cases when it is necessary to interact with university structures. Such foreigners are less involved in communication with classmates, because they often do not live in a dormitory, and all their extracurricular time is occupied with arranging personal relationships. If these relations pass the time test, then decisions are made about options for further stay in Russia or joint departure abroad.

A special motivation for entering a university is the desire to "grow", to improve their status in the minds of representatives of the community, the diaspora or the migrant group. This motivation is typical for representatives of neighbouring countries. Being fluent in Russian and having considerable experience of living in Russia, they do not study at the preliminary training departments. They take the bachelor's degree courses and most often study off-campus. As a rule, these are middle-aged people in the status of a working migrant, which have not got a higher education degree in their homeland. This is not easy for them, but the status of a student, and ideally the diploma of higher 
education, is an opportunity to improve their status in the minds of those they have to communicate with or depend on most. In fact, entering a university becomes a social elevator regardless of academic success. It is significant that the choice of courses, on the one hand, is determined by the applicants' ideas about where it will be easiest to study, and on the other hand, by the experience of other experienced members of the group.

Studying in a regional university can be considered by a foreign citizen as an opportunity to subsequently transfer to the capital or the leading federal university and move to the central regions of the country. It is easier to enter a regional university, as the amount of both Russian and international applicants is significantly higher in the capital universities. Another motif motive of choosing such a way can be the necessity to estimate risks and ability to adjust to the new country and the new way of life. "I have started in Irkutsk in order to understand if I can live in Russia, if I can get familiar and how long will it take it will take", comments the Mongolian university applicant. Such students start to search for the opportunities to move from the very first months if they decide that studying in Russia is a proper decision for them.

There is another less popular strategy of obtaining the student status by foreign female citizens. They are misguided that the Russian citizenship can be obtained by the right of land and decide to come to Russia on a student visa in order to stay and give birth to a child. Such strategy is typical for the foreigners from distant poor and/ or unsafe countries: Syrian Arab Republic, Philippines, Afghanistan. This strategy may be associated with the strategy of creating a family with a Russian citizen, but is often implemented as an independent one. Such practices have become possible due to the development of the system of remote submission of documents for applicants (primarily those entering additional educational programmes) via the Internet. University services involved in the recruitment of foreign citizens, for example, for programmes of Russian as a foreign language, cannot check if the person is pregnant by their passport and questionnaire. Thus, the "problem" is revealed when they meet in person. Having learned about the impossibility of obtaining the citizenship of the Russian Federation for the child by the fact of their birth on its territory, foreigners usually leave for their homeland. But there are cases when foreign citizens, despite explanations from university services, try to use the birth of a child as a way to gain a foothold in Russia.

The foreigners who use the student status to travel around the country of study can be outlined as a separate category. These international students combine study and travel, and often the student status is only the means of exploring the region. The 
fact that a student visa will be actively used for travelling becomes clear even at the stage of correspondence. Such students (most often applying for Russian as a foreign language programme) already at the approval stage ask to indicate in the invitation a period of stay that exceeds the period of study not just for a few days, but for two or three weeks. They answer the clarifying questions that they already have a plan how to spend time after (or before) the start of classes. A visit to several famous Russian cities, a hike in the mountains, participation in a volunteer ecological camp, a trip along the Trans-Siberian Railway, a study tour to a neighbouring region: there may be many options. Such "travelling students" are more common among those who come to summer schools, short-term programmes, but there are also those who take basic educational programmes. Representatives of the latter category are always known "by sight" in the international department of the university, since after each trip foreign citizens must come for re-registration.

\section{Conclusion}

For a certain group of international students, the status of a student can bring some advantages, in particular, simplify the scheme for obtaining a work permit or give the right to stay legally in Russia if obtaining a diploma and education are not the main task. Here, the student status itself is a resource. At the same time, the options for commodification of the status by an international student are not at all related only to the possibility of working. It seems that the practices on the use of the student status to obtain intangible benefits are much more applicable.

Commodification options discussed in this article are just a small list of those practices that can be identified by analysing the motivation of foreign students to enter a regional Russian university. Of course, some of the described practices are quite local due to the geographical location and the "regional" status of the university itself. However, they allow us to confidently say that the relations between Russian universities and international students, of course, should be analysed from the position of recognition of the subjectivity of the latter. Studying at a university is not always a goal in itself. Often it is a tool to achieve completely different goals, a means of implementing a wide range of migration and other strategies. In this perspective, the further identification and study of such practices of the student status commodification provides ample opportunities to study the migration strategies of young people arriving in the regions of Russia, as well as building a successful university internationalisation strategy. 


\section{References}

Grebennikova, I.A. (2010). Pedagogicheskoe soprovozhdenie adaptatsii inostrannykh studentov $v$ rossiiskom vuze (na primere kitaiskikh studentov) [Pedagogical support of adaptation of international students in a Russian university (on the example of Chinese students)]. Thesis of Candidate of Pedagogy, Amursky Humanities and Pedagogy University, Birobidzhan.

Huang, T. (2014). Faktory adaptatsii inostrannykh studentov v Rossii (na primere obsledovaniia studentov iz KNR v vuzakh Sankt-Peterburga) [Factors of adaptation of foreign students in Russia (surveys of Chinese students in the universities of St. Petersburg)]. Sotsiologiia i pravo [Sociology and Law], 3 (25), 30-35.

Kak inostrantsu podgotovitsia $\mathrm{k}$ postupleniiu $\mathrm{v}$ rossiiskii vuz [How a foreigner can prepare for entering a Russian university]. In Study in Russia. Available at: https:// studyinrussia.ru/actual/articles/kak-inostrantsu-podgotovitsya-k-postupleniyu-vrossiyskiy-vuz/ (accessed June 30 2018)

Leont'eva, E.O. (2016). Kitaiskie student v dalnevostochnykh vuzakh: stereotypy i real'nye motivatsionnye ustanovki (na primere g. Khabarovska) [Chinese students in Far Eastern universities: stereotypes and real motivation (on the example of Khabarovsk)]. In Kul'tura i nauka Dal'nego Vostoka [Culture and science of the Far East], 2, 36-40.

Liakh, P.P. (2015). Inostrannye studenty v universitete Tvente (Niderlandy) i TOGU (Rossiia): nekotorye sravnitel'nye parametry sotsial'noi adaptatsii [International students in the University of Twente (the Netherlands) and Pacific National University (Russia): some comparative parameters of social adaptation]. In Uchenye zametki TOGU [Research notes of Pacific National University], 1 (6), 268-283.

Olga Vasil'eva: interes inostrantsev $\mathrm{k}$ rossiiskomu obrazovaniiu rastet [Olga Vasilyeva: foreigners are more and more interested in Russian education]. In RIA novosti. Rossiia segodnia [RIA news. Russia today]. Available at: https://ria.ru/ interview/20180305/1515648167.html (accessed 30 June 2018)

Otchety o mezhdunarodnoi deiatel'nosti Irkutskogo gosudarstvennogo universiteta za period s 2006-2018 god [Reports on international activities of Irkutsk State University for the period from 2006 to 2018]. In Arkhiv upravleniia mezhdunarodnykh sviazei Irkutskogo gosudarstvennogo universiteta [Archives of the International Department of Irkutsk State University].

Pan'kova, N.M., Pogukaeva, N.V. \& Khaldeeva, M.A. (2017). Kommodifikatsiia znaniia $\mathrm{v}$ sisteme vysshego obrazovaniia [Commodification of knowledge in the 
system of higher education]. In Vestnik nauki Sibiri [Newsletter of science in Siberia], 3 (26), 81-89.

$V 2016$ godu turpotok iz Kitaia po bezvizovomu kanalu vyros bolee chem na 40\% po otnosheniiu k predydushchemu godu [In 2016 the tourist flow from China increased by more than $40 \%$ in comparison with the previous year]. Available at: https://www. russiatourism.ru/news/12260/ (accessed 30 June 2018).

Zhu, J. (2016). Chinese Overseas Students and Intercultural Learning Environments: Academic Adjustment, Adaptation and Experience. In Springer.

\section{Иностранные студенты в сибирском вузе: неформальные практики коммодификации статуса}

Ю.В. Елохина

Иркутский государственный университет Россия, 664003, Иркутск, ул. Карла Маркса, 1

Статья представляет разнообразие форм коммодификаџии иностранными студентами своего статуса. Анализ отношений российских вузов и иностранных студентов построен с позиции признания субъектности иностранных обучающихся. Автор, опираясь на промежуточные результаты исследования, основанного на серии полуструктурированных интервью с иностранныли обучающимися, показывает, что обучение в университете нередко является средством реализации широкого спектра миграционных и иных стратегий.

Ключевые слова: иностранные студенты, коммодификачия, неформальные практики. Научная специальность: 22.00.00 - социология. 